\title{
Maternal Awareness and Knowledge of Proper Oral Health during Pregnancy and Post-Delivery and Caries Transmission to their Children
}

\section{Gisela Berenstein Ajzman ${ }^{1 *}$, Myriam Shalom², Offer Erez ${ }^{3}$, Cohen Ornit $^{4}$ and Uri Zilberman ${ }^{2}$}

${ }^{1}$ Pediatric Dentistry Department, Goldshlager Dental School, Tel Aviv University, Israel

${ }^{2}$ Pediatric Dentistry Department, Barzilai University Medical Center, Ashkelon, Israel

${ }^{3}$ Director (Director Maternity "D" and Obstetrical Day Care Unit, Obstetrics and Gynecology Division), Soroka University Medical Center, Israel

${ }^{4}$ Wolfson Medical Center, Holon, Israel

*Corresponding Author: Gisela Berenstein Ajzman, Pediatric Dentistry

Department, Goldshlager Dental School, Tel Aviv University, Israel.
Received: June 24, 2021

Published: August 10, 2021

(C) All rights are reserved by Gisela

Berenstein Ajzman., et al.

\begin{abstract}
Background: Maternal knowledge and awareness may play an essential positive role in the prevention of early childhood caries (ECC) that bears significant risks and even life-threatening infections. Therefore, improving maternal knowledge and practice of oral health during pregnancy may result in lower risks of ECC in toddlers and children.

Aims: To explore post-partum maternal knowledge and awareness of caries and its prevention and elucidate the association between sociodemographic variables and this knowledge.

Design: This survey cohort study of a questionnaire regarding maternal knowledge on oral health habits included 100 parturients at the Soroka University Medical Center, during 2015.

Results: Mothers had good oral health care habits; however, these habits did not correlate with knowledge and awareness about caries prevention. About $60 \%$ of the mothers did not know that caries is a contagious disease. Only $10 \%$ of the mothers were referred to a dental check-up during the year prior to delivery. Mothers with academic education had better knowledge than others ( $p=0.029)$. Mothers who gave birth for the first time had significantly less knowledge than experienced ones $(p=0.002)$.

Conclusion: Maternal knowledge on oral health hygiene's is related to her level of education and parity. Therefore, it is necessary to initiate an educational program for pregnant women to promote oral health care and nutritional recommendation to improve caries prevention in children.
\end{abstract}

Keywords: Dental Caries; Oral Health Care; Mother's Education; Pregnancy; Post-Partum

\section{Introduction}

Dental caries is a chronic oral infection. Even though caries prevalence has been dramatically reduced, mostly due to fluoride treatment, it is still the most common oral disease [1]. Dental car- ies is a preventable contagious chronic disease, whose outcomes are determined by the dynamic balance between pathological factors that lead to tooth demineralization and protective factors that lead to their remineralization [2]. Early childhood caries (ECC) is 
a virulent form of dental caries, prevalent among children under six years old, affecting $44 \%$ of children in the USA. This virulent form bears significant risks of dental occlusion disorder, eating problems, delayed child development, pain, and even life-threatening infections [2-6]. Studies have shown that early acquisition of cariogenic bacteria was associated with ECC and connected to the severity of the disease [7]. A window of infectivity was found at the ages of 19 - 33 months when most bacterial colonization occurs [3]. Early-onset of ECC was associated with Cesarean delivery [7,8], consumption of sweet beverages and snacks, and nocturnal bottle feeding $[4,9]$.

Caries-producing bacteria belong to two major groups: The Streptococci and the Lactobacilli. These bacteria ferment carbohydrates and produce organic acids. The acidity may fall to a point where tooth enamel demineralization will occur. The "critical $\mathrm{pH}^{\text {" }}$ value for demineralization is about 5.5 [6]. Transmission of these bacteria can occur either horizontally between siblings and classmates or vertically from mother to child for example: when sharing a spoon [7]. In $71 \%$ of the cases, this transmission was shown by identifying the same bacterial genotype isolated from both mother and child [3].

The association between the mother's oral health and ECC has been previously investigated [4,10-12]. Mothers who underwent anti-cariogenic dental care reduced their children's exposure to cariogenic bacteria, and thereby ECC development $[4,11]$. Moreover, improving maternal oral health during pregnancy resulted in lower risks of ECC in newborns and children [12]. Studies have found correlations between caries severity and socioeconomic status, maternal age, educational level, and parents' ethnicity or immigrant status [13-15].

Recommendations have been suggested for mothers to take care of their oral health to prevent caries among their children [16-23].

\section{Aim of the Study}

The aim of this cohort survey was to elucidate the association between sociodemographic variables and oral health care knowledge among parturient in maternity department.

\section{Methods}

\section{Participants}

After informed consent and prior approval from the Ethical Committee on Experiments on Humans (Helsinki Committee), one hundred volunteers were recruited. All were post-delivery mothers recovering after birth at the maternity ward at the Soroka Medical Center, Beer-Sheva, Israel, throughout 2015.

Questionnaire: Knowledge and awareness about the prevention of caries in children and sociodemographic and educational factors were surveyed in a representative sample of 100 mothers, using a questionnaire. The questionnaire contained 10 questions about demographic and general health status, such as age, marital status, education, economic status (Appendix 1). Following 12 yes/no questions about oral health care habits, then 17- statement questions to assess common conceptions about caries, transmission, and oral health. Knowledge and awareness were evaluated on a 3-point scale (right, wrong, do not know). These statements were formulated following the principles of the American Academy Pediatric Dentistry (AAPD). Finally, 5 complementary general questions were asked.

\section{Data analysis}

After anonymous questionnaires were collected from participants, the data was statistically analyzed. Prevalence analyses and chi-square tests were used to investigate categorical variables for background data such as marital status (single vs. married mothers), at-risk pregnancy, first birth or high birth order, and socioeconomic status. For each of the following variables: Maternal oral health care habits, and Maternal knowledge of oral hygiene and caries transmission, a score was determined as the sum of correct answers given on the subject. Pearson's correlation coefficients were calculated to evaluate relationships between the variables and other quantitative variables, such as education levels. Student's t-test and one-way analysis of variance (ANOVA) were used to compare single and married mothers, at-risk and normal pregnancies, IVF and spontaneous pregnancy, and socioeconomic status. Multiple regression analysis was applied to examine the determinants of knowledge and awareness. Multi-logistic regression equations were used to predict the answer for a specific item in the questionnaire. Using regression equations allowed an examination of the relative contribution of each variable. All results were expressed as means \pm standard deviations; a p-value less than 0.05 was regarded as statistically significant.

\section{Results}

Sociodemographic variables

The study population $(n=100)$ had a mean age of $30.37 \pm 5.6$ years, and the mean gestational age at delivery was $38.9 \pm 1.7$ weeks. Ninety-eight percent of the mothers were married, and the 
mean number of persons per household was $4.76 \pm 1.9$. The distribution of maternal education was as follows: $44 \%$ high-school graduates, $10 \%$ above high-school education, and $46 \%$ academic education. Sixty percent declared an income of less than the average income in Israel at the time of the study, indicating a low socioeconomic level. Fifty-seven percent were born in Israel, and 45\% were living in Beer Sheva. Most of the participants (73\%) had a normal pregnancy ( $27 \%$ at risk). It was the first birth for $25 \%$ of the mothers, $26 \%$ the second birth, $25 \%$ the third birth, and $12 \%$ the fourth birth and beyond. Only $3 \%$ of the women in the study group reported miscarriages in the past, $94 \%$ became pregnant spontaneously, and $84 \%$ gave birth vaginally (not by cesarean section).

\section{Mother's oral health care habits}

Most mothers (64\%) reported brushing their teeth twice a day, with an average of $1.9 \pm 0.6$ times per day. Thirty-five stated that they had visited the dentist regularly: $38 \%$ reported that they visited less often than every two years, $21 \%$ once every two years, $26 \%$ reported a visit once a year, $15 \%$ once every six months. Thirty-nine percent have undergone dental care in the last year, and $79 \%$ have undergone dental care in the last three years. Table 1 specifies the most relevant habits. Interestingly, only $10 \%$ of the mothers were referred to a dental check-up during the year prior to delivery. Most of them were referred by a dental hygienist rather than their family doctor or gynecologist.

\begin{tabular}{|l|c|}
\hline \multicolumn{1}{|c|}{ General and oral health habits } & "Yes" answer (\%) \\
\hline Consumes calcium-containing foods & 97 \\
\hline $\begin{array}{l}\text { Had an appointment at the dentist in the } \\
\text { last three years }\end{array}$ & 79 \\
\hline Drinks carbonated soft drinks ${ }^{\ddagger}$ & 66 \\
\hline Chews sugar-free gum & 66 \\
\hline Uses dental mouthwash & 47 \\
\hline $\begin{array}{l}\text { Underwent dental care treatment in the } \\
\text { last year }\end{array}$ & 39 \\
\hline Regular physical exercise & 38 \\
\hline Regular dental check-up & 35 \\
\hline $\begin{array}{l}\text { Participated in a childbirth preparation } \\
\text { course }\end{array}$ & 22 \\
\hline $\begin{array}{l}\text { Was referred to a dental check-up in the } \\
\text { last year }\end{array}$ & 10 \\
\hline Smoking & 12 \\
\hline $\begin{array}{l}\text { Had an appointment to a dental hygienist } \\
\text { during pregnancy }\end{array}$ & 11 \\
\hline
\end{tabular}

Table 1: Prevalence of oral health habits among the population sample.

${ }^{\dagger}: \mathrm{n}=100 ;{ }^{\ddagger}:$ Negative Habits.
We calculated a score of general and oral health habits for each mother participating in the study by adding all stated positive minus negative patterns. The evaluated scores showed a normal distribution curve with an average value of $39.65 \pm 13.66$ points (Figure 1).

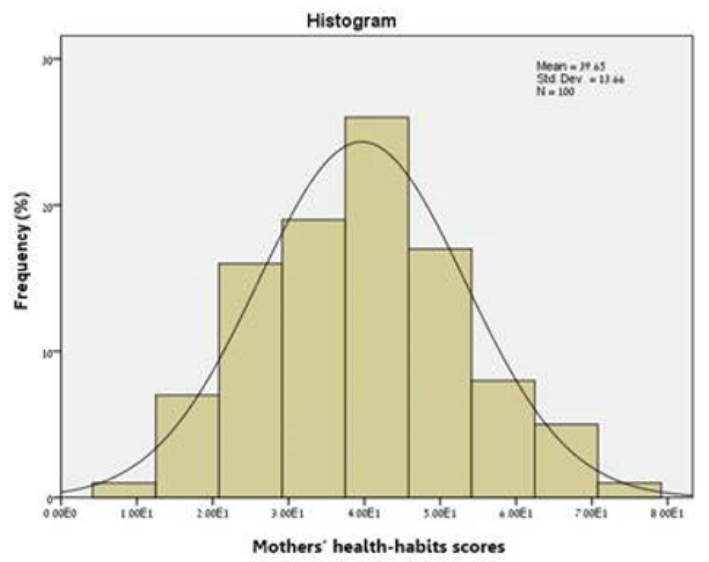

Figure 1: Distribution of health-habits scores in the sample population of mothers. The solid line shows a simulated normal (Gaussian) distribution. Scores were calculated for each mother participating in the study by adding all stated positive minus negative habits. $\mathrm{n}=100$.

Mother's knowledge about the oral hygiene of the baby and caries transmission

We calculated a score of knowledge about oral health for each mother participating in the study by the ratio of correct answers. The calculated scores showed a normal distribution curve with an average value of $54.8 \pm 14.9$ points (Figure 2 ).

About half of the mothers (51\%) did not know that their oral hygiene influenced their babies' oral health. Forty-one percent of the participants did not know the importance of keeping a balanced diet during pregnancy to develop their babies' teeth properly. Most of the misconceptions that were observed here were on the following statements (Table 2): a) Caries is a contagious disease $(57 \%$ were wrong). b) Transmission of caries mostly occurs from mother (as the premier caretaker) to son (58\% wrong). c) Milk feeding at nighttime using bottle-feeding may promote caries development (36\% wrong). d) The first visit for a check-up at the dentist's clinic should be made at 6-12 months of age (38\%). 


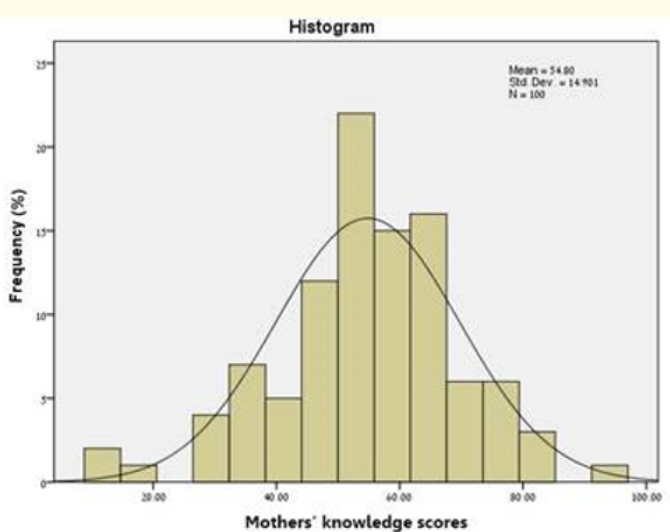

Figure 2: Distribution of mothers' knowledge about oral hygiene and caries disease. The solid line shows a simulated normal (Gaussian) distribution. Scores were calculated for each mother in the study as a ratio of correct answers, out of 12 questions. $n=100$.

\begin{tabular}{|l|c|c|c|}
\hline \multicolumn{1}{|c|}{ Statement } & $\begin{array}{c}\text { Don't } \\
\text { know }\end{array}$ & Right & Wrong \\
\hline $\begin{array}{l}\text { Mother's oral health influences } \\
\text { the baby's teeth condition. }\end{array}$ & 51 & 30 & 19 \\
\hline $\begin{array}{l}\text { A balanced diet during the } \\
\text { pregnancy influences baby's teeth } \\
\text { optimal development. }\end{array}$ & 41 & 50 & 9 \\
\hline $\begin{array}{l}\text { The first dental check-up should } \\
\text { be scheduled at 6 - 12-month age. }\end{array}$ & 37 & 35 & 28 \\
\hline $\begin{array}{l}\text { Children of mothers with caries } \\
\text { have a higher risk for caries. }\end{array}$ & 35 & 45 & 20 \\
\hline $\begin{array}{l}\text { Caries in primary teeth may influ- } \\
\text { ence permanent teeth health. }\end{array}$ & 35 & 47 & 18 \\
\hline $\begin{array}{l}\text { Using fluoride containing tooth- } \\
\text { past is recommended for children } \\
\text { above two years old. }\end{array}$ & 34 & 53 & 13 \\
\hline $\begin{array}{l}\text { The baby is infected with } \\
\text { cariogenic bacteria mainly from } \\
\text { his mother. }\end{array}$ & 33 & 9 & 58 \\
\hline $\begin{array}{l}\text { Prolonged (over a year), } \\
\text { breastfeeding harms the baby's } \\
\text { teeth health. }\end{array}$ & 32 & 46 & 22 \\
\hline $\begin{array}{l}\text { Milk feeding at nighttime using } \\
\text { bottle-feeding may promote caries } \\
\text { development. }\end{array}$ & 30 & 34 & 36 \\
\hline
\end{tabular}

\begin{tabular}{|l|c|c|c|}
\hline $\begin{array}{l}\text { Caries is a contagious disease like } \\
\text { any other disease. }\end{array}$ & 27 & 16 & 57 \\
\hline Caries is caused by bacteria. & 23 & 69 & 8 \\
\hline $\begin{array}{l}\text { Caries is caused by acids secreted } \\
\text { by bacteria that feed on sugar } \\
\text { residues in the oral cavity. }\end{array}$ & 17 & 78 & 5 \\
\hline $\begin{array}{l}\text { It is recommended to brush the } \\
\text { baby's teeth right from the first } \\
\text { tooth. }\end{array}$ & 16 & 60 & 24 \\
\hline Caries is a preventable disease. & 13 & 85 & 2 \\
\hline $\begin{array}{l}\text { Sweetened drink consumption } \\
\text { at nighttime using bottle-feeding } \\
\text { may promote caries development. }\end{array}$ & 7 & 89 & 4 \\
\hline $\begin{array}{l}\text { Keeping oral hygiene at an early } \\
\text { age may prevent caries later in } \\
\text { childhood. }\end{array}$ & 5 & 90 & 5 \\
\hline $\begin{array}{l}\text { Water is the main recommended } \\
\text { drink for children. }\end{array}$ & 2 & 96 & 2 \\
\hline
\end{tabular}

Table 2: Distribution (\%) of mothers' answers on statements about oral hygiene and caries disease.

However, most mothers correctly answered the following issues: a) Water is the main recommended drink for children (97\%). b) It is essential to maintain oral hygiene to prevent caries (90\%). c) Sweet drink consumption at night is not recommended (89\%). d) Caries is a preventable disease (85\%). More than $50 \%$ of the mothers knew that using fluoride containing toothpaste is recommended for children above two years old [21,22]. Sixty percent knew that teeth-brushing should begin as soon as the first tooth appears.

Correlations between health care habits and sociodemographic variables

Maternal health care habits scores were negatively correlated to the number of persons per household ( $r=-0.226$; $p=0.001$ ). It was observed that the higher the number of persons per household, the lower the practice of good oral health habits. Additionally, good health habits were significantly correlated to maternal educational level ( $r=0.199 ; p=0.001)$.

Correlations between knowledge and sociodemographic variables

Maternal knowledge scores were significantly correlated to their educational level. The more educated the mother was, the more she knew about oral hygiene and caries transmission. Moth- 
ers who had academic education $(n=46)$ had a mean knowledge score of $55.6043 \pm 14.28$ ( $\mathrm{p}=0.029$ ), as compared to mothers who had higher than high school education $(n=10)$ with a score of $64.68 \pm 14.92$; and high-school graduates $(n=44)$ scored 51.7173 \pm 14.76 points.

Primiparous women knowledge score regarding oral health care and caries was lower than that of multiparous patients (primiparous $47.9 \pm 18.28$ vs. multiparous $57.8 \pm 12.04, p=0.002$ ).

No correlation was found between the mother's oral health care habits and knowledge. Additionally, we did not find any correlation between knowledge and declared income, at-risk pregnancy, or birth outcomes.

Using the Linear regression model, we could not identify any sociodemographic factor as a predictor for knowledge about oral health and caries transmission.

\section{Discussion}

This study explored the knowledge and awareness of mothers to caries and its prevention, taking into consideration sociodemographic variables and oral health care among parturients.

We found that members of the study population were familiar with good oral health habits. For example, most mothers (64\%) reported brushing their teeth twice a day, and 35\% stated that they had visited the dentist regularly. Mothers' health care habits scores were significantly correlated to the number of persons per household and their educational level. However, these good habits did not correlate with their knowledge and awareness about caries and its prevention.

Our observations showed a lack of comprehensive knowledge about caries, its causes risk factors and results among mothers in the study population. About $60 \%$ of the mothers did not know that caries is a contagious disease and that the main route of transmission is from mother to son. Studies in the literature have shown this correlation between mothers' oral health and ECC onset $[7,8,12]$ but the information did not reach the general public. Only $10 \%$ of the mothers were referred to a dental check-up during the year before birth. Most of them were referred by a dental hygienist rather than their family doctor or gynecologist. Pregnant women usually undergo a routine follow-up, creating opportunities for educational interventions and information support on oral health and caries prevention. Our findings suggest the need to recommend educational interventions for pregnant women and collaborations between family doctors, gynecologists, and dentists.

Our study showed that the more educated the mother was, and the fewer the members in her family, the better her health habits were. Educated mothers were better informed than mothers with low education levels and many persons per household. These findings correlate with the study of Hale., et al. who reported a high prevalence of caries among children from a low socioeconomic background with less educated mothers, that consumed sugary foods and were 32 times more likely to have caries at the age of 3 years than children in whom those risk factors were not present [21]. Therefore, educational interventions' main target is acquiring awareness among pregnant women of less education and many children. Education may also advise balanced nutrition and dental care during pregnancy to ensure optimal teeth development during the perinatal and prenatal period.

The present study shows that mothers who gave birth for the first time knew about oral health care and caries significantly less than experienced mothers, suggesting an advanced learning process whilst raising children and dealing with their dental problems. Inclusion of dental health education as part of the prenatal follow up during the first pregnancy will provide a better understanding and prevention of caries in the community.

Apart from education and the number of persons in the household, we did not find any correlation between knowledge and sociodemographic variables, including declared income, at-risk pregnancy, or birth outcomes. Moreover, we could not identify any factor as a predictor for the knowledge parameter. These results suggest that knowledge gaps were not specific to a particular socio demographic sector but include the entire population. The normal distribution curves describing both health habits and health knowledge support that assumption. Therefore, recommended education should target all pregnant women, focusing on less-educated future-mothers and mothers of many children.

\section{Conclusion}

In conclusion, the present study confirmed the correlation between mothers' educational level, the number of persons per household and oral health habits. Maternal knowledge was also significantly correlated to their educational level. The more educated the mother was, the more she knew about oral hygiene and caries transmission. However, gaps in knowledge were observed 
in the entire population. It is necessary to initiate educational programs for pregnant women to promote oral health care and nutritional recommendation issues to improve caries prevention.

Why this paper is important to pediatric dentists

- The study reveals insufficient public knowledge about caries as a contagious disease and ways to prevent it.

- The study demonstrates that the less educated the mother was and the more persons per household she had, the less practice of good habits and knowledge were observed.

- Pediatric dentists are encouraged to cooperate with family doctors and gynecologists to recommend balanced nutrition and dental care during pregnancy to ensure optimal teeth development during the perinatal and prenatal period.

\section{Appendix I: Questionnaire}

The translated (from Hebrew) questionnaire for health habit and knowledge about oral health and carries transmission:

\section{Sociodemographic status:}

a. Date of birth

b. Marital status: married / bachelor / divorced / widow

c. Ethnic origin

d. Mother's education: years of education: ...... high-school education / above high-school / academic.

e. Socioeconomic status: What is your family income? Below $12,300^{*}$ IS per month? / Above 12,300 IS? / above 20,000 IS? * The average income in Israel at the time.

f. Housing conditions: city:.........zone:........ number of persons in the household:...

g. Was the current pregnancy at risk? Y/N

h. Is this your first birth? $\mathrm{Y} / \mathrm{N}$

i. Was the current pregnancy a spontaneous pregnancy? Y/ $\mathrm{N}$, it was achieved via IVF.

j. Did you give birth by cesarean section? Y/N after how many weeks of pregnancy?..........

\section{Health-habits: Please mark $X$ in the appropriate box.}

\begin{tabular}{|c|c|c|}
\hline Question & Yes & No \\
\hline Do you Smoke? & & \\
\hline Do you exercise regularly? & & \\
\hline Do you drink carbonated soft drinks? & & \\
\hline Do you consume calcium-containing foods? & & \\
\hline Do you go to a dental check-up regularly? & & \\
\hline $\begin{array}{l}\text { Did you undergo dental care treatment in the } \\
\text { last year? }\end{array}$ & & \\
\hline $\begin{array}{l}\text { Did you have an appointment at the dentist in } \\
\text { the last three years? }\end{array}$ & & \\
\hline $\begin{array}{l}\text { Did you have an appointment with a dental } \\
\text { hygienist during the pregnancy? }\end{array}$ & & \\
\hline Do you chew sugar-free gum? & & \\
\hline Do you use dental mouthwash? & & \\
\hline $\begin{array}{l}\text { Did anyone refer you to a dental check-up in the } \\
\text { last year? }\end{array}$ & & \\
\hline $\begin{array}{l}\text { Did you participate in a childbirth preparation } \\
\text { course? }\end{array}$ & & \\
\hline
\end{tabular}

Table A

\section{Knowledge: Please mark $X$ in the appropriate box.}

\begin{tabular}{|l|l|l|l|}
\hline \multicolumn{1}{|c|}{ Statement } & $\begin{array}{l}\text { Don't } \\
\text { know }\end{array}$ & Right & Wrong \\
\hline $\begin{array}{l}\text { A balanced diet during pregnancy } \\
\text { influences the baby's teeth' optimal } \\
\text { development. }\end{array}$ & & & \\
\hline $\begin{array}{l}\text { Mother's oral health influences the } \\
\text { baby's teeth condition. }\end{array}$ & & & \\
\hline $\begin{array}{l}\text { Children of mothers with caries have a } \\
\text { higher risk for caries. }\end{array}$ & & & \\
\hline Caries is caused by bacteria. & & & \\
\hline $\begin{array}{l}\text { The baby is infected with cariogenic } \\
\text { bacteria mainly from his mother. }\end{array}$ & & & \\
\hline $\begin{array}{l}\text { Caries is a contagious disease like any } \\
\text { other disease. }\end{array}$ & & & \\
\hline Caries is a preventable disease. & & & \\
\hline $\begin{array}{l}\text { Caries is caused by acids secreted by } \\
\text { bacteria that feed on sugar residues in } \\
\text { the oral cavity. }\end{array}$ & & & \\
\hline $\begin{array}{l}\text { Caries in primary teeth may influence } \\
\text { permanent teeth health. }\end{array}$ & & & \\
\hline $\begin{array}{l}\text { It is recommended to brush the baby's } \\
\text { teeth right from the first tooth. }\end{array}$ & & & \\
\hline
\end{tabular}




\begin{tabular}{|l|l|l|l|}
\hline $\begin{array}{l}\text { Prolonged (over a year), breastfeeding } \\
\text { harms the baby's teeth health. }\end{array}$ & & & \\
\hline $\begin{array}{l}\text { Sweetened drink consumption at } \\
\text { nighttime using bottle-feeding may } \\
\text { promote caries development. }\end{array}$ & & & \\
\hline $\begin{array}{l}\text { Milk consumption at nighttime using } \\
\text { bottle-feeding may promote caries } \\
\text { development. }\end{array}$ & & & \\
\hline $\begin{array}{l}\text { Water is the main recommended drink } \\
\text { for children. }\end{array}$ & & & \\
\hline $\begin{array}{l}\text { Keeping oral hygiene at an early age may } \\
\text { prevent caries later in childhood. }\end{array}$ & & & \\
\hline $\begin{array}{l}\text { The first dental check-up should be } \\
\text { scheduled at 6-12-month age. }\end{array}$ & & & \\
\hline $\begin{array}{l}\text { Using fluoride-containing toothpaste is } \\
\text { recommended for children above two } \\
\text { years old. }\end{array}$ & & & \\
\hline
\end{tabular}

Table B

We will appreciate some more detailed answers. Please answer the following questions (more than 1 answer is optional):

- How many times a day do you brush your teeth?

- When during the day do you brush your teeth? Morning/ noon/evening/night

- How often do you visit the dentist? Once every 6 months/ once a year/once in 2 years/less often.

- Do you use mouthwash? What kind of mouthwash do you use?

- If you were referred to a dentist during pregnancy, who were you referred by? Your gynecologist?/Your family doctor?/ your dental hygienist?

\section{Bibliography}

1. Selwitz RH., et al. "Dental caries”. Lancet 369.9555 (2007): 5159.

2. Featherstone JD. "The continuum of dental caries--evidence for a dynamic disease process". Journal of Dental Research 83 (2004): C39-C42.

3. Caufield PW., et al. "Initial acquisition of mutants streptococci by infants: evidence for a discrete window of infectivity". Journal of Dental Research 72 (1993): 37-45.
4. Ribeiro NM RMA. "Breastfeeding and early childhood caries: a critical review". The Journal of Pediatrics 80 (2004): S199S210.

5. Sheiham A. "Dental caries affects body weight, growth and quality of life in pre-school children". The British Dental Journal 201.10 (2006): 625-626.

6. Stewart RE and Hale KJ. "The paradigm shift in the etiology, prevention, and management of dental caries: its effect on the practice of clinical dentistry". The Journal of the California Dental Association 31 (2003): 247-251.

7. Berkowitz RJ. "Mutans streptococci: acquisition and transmission". Paediatric Dentistry 28 (2006): 106-198.

8. Berkowitz RJ. "Causes, treatment and prevention of early childhood caries: a microbiologic perspective". Journal of the Canadian Dental Association 69 (2003): 304-307.

9. Tinanoff $\mathrm{N}$ and Palmer CA. "Dietary determinants of dental caries and dietary recommendations for preschool children". Refuat Hapeh Vehashinayim 20 (2003): 8-78.

10. Hirsch GB., et al. "A simulation model for designing effective interventions in early childhood caries". Preventing Chronic Disease 9 (2012): 110219.

11. Kohler B and Andreen I. "Influence of caries-preventive measures in mothers on cariogenic bacteria and caries experience in their children". Archives of Oral Biology 39 (1994): 907-911.

12. Brambilla E., et al. "Caries prevention during pregnancy: results of a 30-month study". Journal of the American Dental Association 129.7 (1998): 871-877.

13. Ismail AI., et al. "Determinants of early childhood caries in low-income African American young children". Paediatric Dentistry 30 (2008): 289-296.

14. Kim Seow W. "Environmental, maternal, and child factors which contribute to early childhood caries: a unifying conceptual model". International Journal of Paediatric Dentistry 22 (2012): 168.

15. Niji R., et al. "Maternal age at birth and other risk factors in early childhood caries". Paediatric Dentistry 32 (2010): 493498.

16. Burt BA. "The use of sorbitol- and xylitol-sweetened chewing gum in caries control [published correction appears in". Jour- 
nal of the American Dental Association 137.4 (2006): 447.

17. Edgar WH. "A Role for Sugar-Free Gum in Oral Health". Journal of Investigative and Clinical Dentistry 10 (1999): 89-93.

18. Soderling E., et al. "Influence of maternal xylitol consumption on mother-child transmission of mutans streptococci: 6-year follow-up". 35.3 (2001): 173-177.

19. Ribeiro LG., et al. "The effect of different formulations of chlorhexidine in reducing levels of mutans streptococci in the oral cavity: A systematic review of the literature". Journal of Dentistry 35.5 (2007): 359-370.

20. Xiao J., et al. "Prenatal Oral Health Care and Early Childhood Caries Prevention: A Systematic Review and Meta-Analysis". Caries Research 53 (2019): 411-421.

21. Hale KJ. "Oral Health Risk Assessment Timing and Establishment of the Dental Home". Pediatrics 111 (2003): 1113.

22. Position paper on Fluoride in dentistry. Dental health department. Ministry of Health Israel 18.7 (2011).

23. Fluoride recommendations for Infants. American Dental Association Guidelines (2020).

Volume 5 Issue 9 September 2021

(C) All rights are reserved by Gisela Berenstein Ajzman., et al. 